Bull. Fac .Agric., Cairo Univ.,65:78-83 (2014).

\title{
EFFECT OF PUTRESCINE AND ALPHA - TOCOPHEROL ON THE VEGETATIVE GROWTH AND FLOWERING OF Celosia argentea var. Cristata L. PLANTS
}

(Received : 26.1. 2014)

\author{
By \\ E. M. Badawy, N. T. Shanan, M. H. Mahgoub*and N. A. Hegazi* \\ Department of Ornamental Horticulture, Faculty of Agriculture, Cairo University \\ * Department of Ornamental Plants and Woody Trees, National Research Centre, Dokki, Giza, Egypt
}

\begin{abstract}
A pot experiment was conducted in the greenhouse of the National Research Centre, Dokki, Giza, Egypt during two successive seasons (2009-2010) and (2010-2011) to study the effect of putrescine $(50,100$ and $200 \mathrm{ppm})$, alpha- tocopherol $(200,400$ and $600 \mathrm{ppm})$ on the vegetative growth and flowering of Celosia argentea var. Cristata L. plants. The data indicated that most criteria of vegetative growth were expressed as plant height, No. of leaves, fresh and dry weight of leaves, stem diameter and fresh and dry weight of the stem as well as inflorescence characters, which are expressed as inflorescence length, inflorescence diameter, fresh and dry weight of inflorescence which were significantly affected by the application of putrescine and alpha- tocopherol compared with the control plants. Foliar application of putrescine at the concentration of $200 \mathrm{ppm}$ gave the highest increase values in the vegetative growth and inflorescence characters as compared with the other treatments and untreated plants in the two seasons of study. Spraying with alpha- tocopherol at the concentration of $400 \mathrm{ppm}$ gave the highest values in the vegetative growth and flowering except for fresh and dry weight of the inflorescence, which gave the highest increase values when the plants were treated with $200 \mathrm{ppm}$ alpha- tocopherol as compared with the control plants.
\end{abstract}

Key words: alpha-tocopherol, celosia cristata, flowering characters, growth, putrescine.

\section{INTRODUCTION}

Celosia argentea var. cristata L. (Cocks comb) is an herbaceous plant of the family Amaranthaceae. It has distinctive characteristic inflorescence which looks like the crest of a rooster or convoluted brain after its full development (Bojian et al., 2003). The attractive inflorescences are usually brightly colored in, red, yellow, pink, or orange though other colors can be present. It is a popular ornamental plant and has some medical purposes such as antiviral proteins, betalains, and anthocyanin (Balasubrahmanyam et al., 2000).

Polyamines are beneficial subgroups of amines, divided into aliphatic di- amine putrescine, triamine spermidine, and tetra amine spermine. These compounds have diverse biological functions and are formed during metabolic processes in the living organisms. Polyamines in plants are involved in many steps of protein synthesis, embryogenesis, transcription of genes, cell division, organ development, fruit ripening, leaf senescence, tuber dormancy and stress minimization. Moreover, there is a strong association between polyamine metabolism in plants and environmental stress, e.g. nutrient deficiency, drought soil salinity or temperature (Kosson and Prange., 2005).

Vitamins could be considered as bio-regulators compounds which in relatively low concentrations exert profound influence on many physiological processes, such as synthesis of enzymes, act as coenzymes and affect plant growth (Reda et al., 2005). Alpha-tocopherol (Vitamin E) is a low molecular weight lipophilic antioxidant, which mainly protect membranes from oxidative damage (Asada, 1999). Zhang et al. (2000) reported a positive correlation between alpha-tocopherol and 
shoot or root growth in two grass species grown under drought. Tocopherols were proposed to function in relation to their antioxidant properties being prominent in the protection of poly unsaturated fatty acids from lipid peroxidation by quenching and scavenging various reactive oxygen radicals. Also, in plants tocopherol levels vary in different tissues and fluctuate during its development and in response to abiotic stresses (Munne-Bosch, 2005).

Therefore, the aim of this investigation was to study the influence of putrescine and alphatocopherol application on the growth and flowering of Celosia argentea var. cristata L. plants, in order to obtain high quality of Celosia cut flowers, especially to be used for flower arrangements and interior decoration.

\section{MATERIALS AND METHODS}

A pot experiment was carried out during two successive seasons of (2009-2010) and (20102011) in the greenhouse of the National Research Centre, Dokki, Giza, Egypt to investigate the influence of putrescine (Put.) and alpha-tocopherol (V.E) application on the growth and flowering of Celosia argentea var. cristata L. plant.

Celosia seedlings were obtained from a commercial private farm for flower production (at Kafr Hakim, Giza). The seedlings were selected in similar shape and size. (Seedlings were $7 \mathrm{~cm}$ in length, with 4 pairs of leaves). The seedlings were individually transplanted on the $15^{\text {th }}$ of June for both seasons in $30 \mathrm{~cm}$ diameter clay pots, filled with $8 \mathrm{~kg}$ growing media consist of loamy clay and sand at the ratio of $1: 1(\mathrm{v} / \mathrm{v})$. After two weeks from transplanting all seedlings received equal dose (4gm/pot) of N.P.K fertilizer (19:19:19) from ammonium nitrate, tri phosphates and potassium sulphate, respectively and were irrigated regularly with tap water. On the $15^{\text {th }}$ of July for both seasons, the plants were sprayed till run off point with two growth regulators namely putrescine: (Put.) at the concentrations of $(0,50,100$ and 200ppm) and alpha-tocopherol (V.E) at the concentrations of $(0,200,400$ and $600 \mathrm{ppm})$, while the control plants were sprayed with tap water. The second spray was carried out after two weeks from the $1^{\text {st }}$ spraying. Thus, seven treatments were carried out, with each treatment replicated three times, each replicate consisted of three plants. The layout of the experiment was completely randomized design. The following data were recorded: plant height $(\mathrm{cm})$, No. of leaves; fresh and dry weight of leaves $(\mathrm{g})$, stem diameter $(\mathrm{cm})$, fresh and dry weight of stem (g), inflorescence length $(\mathrm{cm})$, fresh and dry weight of inflorescence $(\mathrm{g})$ and inflorescence diameter $(\mathrm{cm})$. The data were subjected to statistical analysis of variance according to Snedecor and Cochran (1980).

\section{RESULTS AND DISCUSSION \\ 3.1. Vegetative growth characters}

The data presented in Table (1) showed that foliar application of putrescine (Put.) at rate of 50, 100 and $200 \mathrm{ppm}$ and alpha-tocopherol (V.E) at the concentration of 200, 400 and $600 \mathrm{ppm}$ significantly increased vegetative growth of Celosia plants as compared with the control plants. Application of putrescine at $200 \mathrm{ppm}$, significantly increased plant height with (35.4\%), the number of leaves (38.2\%), fresh (132.6\%) and dry weight $(166.3 \%)$ of leaves, stem diameter $(25.7 \%)$ and fresh $(102.6 \%)$ and dry weight of stem (129.9\%) over the control plants, in the first season. Similar results were obtained in the $2^{\text {nd }}$ season. In this connection, similar results were reported by Youssef et al. (2004b) on Matthiola incana, Youssef et al., (2004a) on datura plants, Abd-El Wahed and Gamal El-Din (2005) on chamomile plants , Talaat and Gamal El-Din (2005) on Nigella sativa, Talaat et al. (2005) on Dianthus caryophyllus plants, Abdel-Aziz et al. (2009) on galdiolus plants, El-Sayed (2009) on chrysanthemum plants, Mahgoub et al. (2011) on Dahlia pinnata plants, and Youssef (2011) on populous species. The obtained results may be attributed to that polyamines had been implicated in a wide range of biological processes including growth development, abiotic stress responses, cell division and differentiation as mentioned by Kuchen and Phillips (2005). Also, Galston (1983) mentioned that polyamines had been considered as regulators for plant growth and development.

Regarding, the effect of alpha-tocopherol on Celosia plants, the data in Table (1) emphasized that all concentrations significantly increased plant growth characters as compared with the control plants, and the application of 400 ppm alphatocopherol resulted in the highest value of all growth parameters. The increments, due to the application ed of $400 \mathrm{ppm}$ putrescine, were (76.44, 
$53.44,30.42,4.89,0.70,42.89$ and $13.68 \%$ ), for plant height, No. of the leaves, F.W. of the leaves,

D.W. of the leaves, stem diameter, F.W. of stem substance in the membranes. Therefore, many attempts had been made to reduce oxidative stress in plants by exogenous application of this vitamin

Table (1): Influence of putrescine and alpha-tocopherol (V.E) on the vegetative growth characters of Celosia argentea var. Cristata $\mathbf{L}$. plant during the first and second seasons.

\begin{tabular}{|c|c|c|c|c|c|c|c|c|c|c|c|c|c|c|}
\hline \multirow{2}{*}{ Treatments } & \multicolumn{2}{|c|}{ Plant height (cm) } & \multicolumn{2}{|c|}{$\begin{array}{c}\text { No. } \\
\text { of leaves }\end{array}$} & \multicolumn{2}{|c|}{$\begin{array}{c}\text { F.W } \\
\text { leaves (g) }\end{array}$} & \multicolumn{2}{|c|}{ D.W leaves (g) } & \multicolumn{2}{|c|}{ Stem diameter $(\mathbf{c m})$} & \multicolumn{2}{|c|}{$\begin{array}{c}\text { F.W } \\
\text { stem (g) }\end{array}$} & \multicolumn{2}{|c|}{$\begin{array}{c}\text { D.W } \\
\text { stem (g) }\end{array}$} \\
\hline & $1^{s t}$ & $2^{n d}$ & $\mathbf{1}^{s t}$ & $2^{n d}$ & $\mathbf{1}^{s t}$ & $2^{n d}$ & $1^{s t}$ & $2^{n d}$ & $\mathbf{1}^{s t}$ & $2^{n d}$ & $1^{s t}$ & $2^{n d}$ & $1^{s t}$ & $2^{n d}$ \\
\hline Control & 60.11 & 82.83 & 42.44 & 46.00 & 15.26 & 29.74 & 2.85 & 7.25 & 0.66 & 0.70 & 22.98 & 40.61 & 5.67 & 10.88 \\
\hline 50ppm Put. & 62.33 & 88.58 & 45.56 & 49.00 & 17.67 & 32.98 & 3.35 & 8.14 & 0.70 & 0.84 & 27.69 & 43.00 & 9.95 & 11.86 \\
\hline 100 ppm Put. & 73.72 & 96.00 & 54.33 & $\mathbf{5 7 . 0 0}$ & 24.27 & 37.82 & 4.99 & 9.87 & 0.80 & 0.92 & 40.77 & 50.6 & 10.92 & 14.59 \\
\hline 200 ppm Put. & 81.39 & 101.67 & $\mathbf{5 8 . 6 7}$ & 60.00 & 35.51 & $\mathbf{5 2 . 3 5}$ & 7.59 & 14.13 & 0.83 & 0.97 & 46.58 & 63.42 & 13.04 & 19.02 \\
\hline 200 ppm V.E & 70.67 & 94.00 & 50.22 & 52.67 & 22.75 & 35.32 & 4.55 & 9.04 & 0.76 & 0.88 & 37.05 & 49.79 & 9.70 & 14.28 \\
\hline 400 ppm V.E & 76.44 & 98.67 & 53.44 & 54.00 & 30.42 & 41.44 & 4.89 & 10.98 & 0.70 & 0.77 & 42.89 & 55.74 & 13.68 & 16.38 \\
\hline 600 ppm V.E & 67.66 & 91.05 & 46.56 & 51.00 & 19.41 & 33.98 & 3.78 & 8.56 & 0.74 & 0.82 & 31.75 & 46.24 & 8.19 & 13.03 \\
\hline LSD at $5 \%$ & 2.4 & 2.97 & 2.62 & 2.94 & 2.41 & 3.57 & 1.23 & 1.4 & 0.03 & 0.04 & 3.49 & 3.54 & 1.00 & 1.45 \\
\hline
\end{tabular}

and D.W. of stem, respectively, over the untreated plants in the $1^{\text {st }}$ season. Similar results were found in the $2^{\text {nd }}$ season. These results are in agreement with those obtained by El-Liethy et al. (2010) on Linum usitatissimum L. plants, El-Bassiouny et al. (2005) on Vicia faba plants. Plant cells could be protected against oxidant stress by various radical - scavenging systems, including low molecular- weight antioxidants such as ascorbate, glutathione, alpha-tocopherol and carotenoids, as well as by antioxidant enzymes such as superoxide dismutases, peroxidase and glutathione reductase (Foyer et al., 1994b). Protection against phytotoxic peroxidation processes; halophilic environments may be achieved by antioxidants, like alpha-tocopherol (V. E), which is assumed to be the most effective radical - chain- breaking
(Foyer et al., 1994a).

\subsection{Flowering characters}

The data presented in Table (2) indicated that both putrescine and alpha-tocopherol treatments significantly increased the mean values of all inflorescence characters as compared with the control treatment.

It was found that foliar application of putrescines at the concentrations of 50, 100 and $200 \mathrm{ppm}$ significantly increased length of the inflorescence, inflorescence diameter and the fresh and dry weights of the inflorescence in the $1^{\text {st }}$ and the $2^{\text {nd }}$ seasons as compared with the control plants. Foliar application of putrescine at $200 \mathrm{ppm}$ gave the highest significant increase in inflorescence characters which recorded $(155,91$, 217.9 and $290.9 \%$ ) compared with the untreated

Table (2): Influence of putrescine and alpha-tocopherol (V.E) on inflorescence of Celosia argentea var.Cristata $\mathbf{L}$. plant during the first and second seasons.

\begin{tabular}{|c|c|c|c|c|c|c|c|c|}
\hline Tre & \multicolumn{2}{|c|}{ Inflorescence length $(\mathrm{cm})$} & \multicolumn{2}{|c|}{ Inflorescence diameter $(\mathrm{cm})$} & \multicolumn{2}{|c|}{ F.W Inflorescence (g) } & \multicolumn{2}{|c|}{ D.W Inflorescence (g } \\
\hline Control & 3.07 & 3.50 & 3.00 & 5.33 & 8.28 & 10.37 & 1.21 & 1.72 \\
\hline 100 ppm Put. & 6.67 & 7.25 & 4.75 & 7.37 & 21.00 & 27.97 & 3.52 & 5.45 \\
\hline 200 ppm Put. & 7.83 & 8.15 & 5.73 & 8.67 & 26.33 & 31.10 & 4.73 & 6.22 \\
\hline 200 ppm V.E & 5.28 & 6.55 & 4.22 & 7.33 & 17.90 & 18.13 & 2.91 & 2.99 \\
\hline 600 ppm V.E & 4.62 & 5.85 & 3.85 & 6.67 & 10.28 & 15.36 & 1.65 & 2.50 \\
\hline LSD at $5 \%$ & 0.55 & 0.60 & 0.39 & 0.47 & 1.96 & 2.15 & 0.24 & $\mathbf{0 . 3 2}$ \\
\hline
\end{tabular}


plants in the $1^{\text {st }}$ season. Also, a similar trend was found in the $2^{\text {nd }}$ one. These results are supported by El-Quesni et al. (2007) on Bougainvillea galbra plants who obtained a significant influence of putrescine on increasing the flower length, flower diameter, fresh and dry weight of the flower. Also, El-Sayed (2009) on chrysanthemum, Mahgoub et al. (2011) on dahlia plants and ElSabwa (2012) on Salvia splendens, obtained similar results. This may be explained as putrescine enhance the accumulation of the production in the plant tissues, i.e flowers. The conjugated polyamines were known to be associated with the physiology of flowering, (Slocum and Glaston 1985).

Concerning the effect of alpha-tocopherol on the inflorescence characters, the data presented in Table (2) indicated that the concentrations of 200 , 400 and $600 \mathrm{ppm}$ significantly increased inflorescence length, diameter as well as, fresh and dry weights, in both seasons as compared with the untreated plants. Spraying the plants with alpha-to alpha-tocopherol copherol at the concentration of $400 \mathrm{ppm}$ gave the highest significant increase in length and diameter of the inflorescence, which recorded $(130.9,121.4 \%)$ and $(70.3,43.9 \%)$ in the $1^{s t}$ and the $2^{\text {nd }}$ season, respectively, compared with the untreated plants, while alpha-tocopherol at the concentration of $200 \mathrm{ppm}$ gave the highest significant increase for fresh and dry weight of the inflorescence, giving (116.1 and 14.4\%) in the $1^{\text {st }}$ season as compared with the untreated plants. Similar trend was found in the $2^{\text {nd }}$ season. These results are in harmony with those obtained by ElQuesni et al., 2009 on Hibiscus rosa sinenses L. plants, El-Liethyet al.(2010) on Falx plant, Eid et al. (2010) on Jasminum grandiflorum plants. Alpha-tocopherol are considered as a group of compounds synthesized only by photosynthetic organisms. Plants treated with alpha- tocopherol are believed to protect chloroplast membranes from photooxidation and help to provide an optimal environment for photosynthetic machinery; Munne-Bosch and Alegre (2002).

From the above mentioned results, it could be concluded that spraying Celosia argentea var.cristata L. plants with $200 \mathrm{ppm}$ of putrescine and $400 \mathrm{ppm}$ of alpha- tocopherol were the most favorable concentrations to give the highest values of growth and flowering characters.

\section{REFERENCES}

Abd El-Aziz N. G., Taha L. S. and Ibrahim S. M. (2009). Some studies on the effect of putrescine, ascorbic acid and thiamine on growth, flowering and some chemical constituents of gladiolus plants at Nubaria. Ozean J. Appl. Sci., 2(2): 169-179.

Abd El-Wahed M. S. A. and Gamal El-Din K. M. (2005). Effect of putrescine and atonic on growth and some biochemical constituents as well as essential oil composition of chamomile plant (Chamomilla recutita L., Rausch). J. Agric. Sci. Mansoura Univ., 30(2): 869-882.

Asada K. (1999). The water-water cycle chloroplasts. Scavenging of active oxygens and dissipation of excess photons. Ann. Rev. Plant Physi. Plant Mol. Biol., 50: 601639.

Balasubrahmanyam A., Baranwal V. K., Lodha M.L.,Varma A. and Kapoor H. C. (2000). Purification and properties of growth stage-dependent antiviral proteins from the leaves of Celosia cristata. Plant Sci., 154: 13-21.

Bojian B., Clemants S.E. and Borsch T. (2003) Amaranthaceae.In: $\mathrm{Wu} \mathrm{ZY}$, Raven PH, Hong DY (eds) Flora of China, Vol. 5 (Ulmaceae through Basellaceae). SciencePress, Beijing, and Missouri Botanical Garden Press,St. Louis, pp 41529.

Eid R. A., Taha L. S. and Ibrahim S. M. (2010). Physiological properties studies on essential oil of Jasminum grandiflorum L. as affected by some vitamins. Ozean J. Appl. Sci., 3(1): 87-96.

El-Bassiouny H. M.S., Gobarah M. E. and Ramadan A. A. (2005). Effect of antioxidants on growth, yield and favism causative agents in seeds of Vicia faba L. plants grown under reclaimed sandy soil. J. Agron., 4: 281-287.

El-Liethy S. R., Ayad H. S. and TalaatI. M. (2010). Physiological effect of some antioxidants on flax plant (Linum usitatissimum L.). World J. Agric. Sci., 6(5): 622-629.

El-Quesni F. E. M, Abd El-Aziz N. G. and Kandil M. M. (2009). Some studies on the effect of 
ascorbic acid and alpha-tocopherol on the growth and some chemical composition of Hibiscus rosa-sinenses L. at Nubaria. Ozean J. Appl. Sci., 2(2): 159-167.

El-Quesni F. E. M., Kandil M. M. and Mahgoub M. H. (2007). Some studies on the effect of putrescine and paclobutrazol on the growth and chemical composition of Bougainvillea glabra L. at Nubaria. American Eurasian J. Agri.\&Environ.Sci., 2(5): 552-558.

El-Sabwa M. N. (2012). Effect of some plant growth regulators on growth and flowering of Salvia splendens L. plant. M.Sc. Thesis, Fac. Agri., Cairo Univ., Egypt, 137pp.

El-Sayed I. M. (2009). Physiological and biological studies on Chrysanthemum indicum L. plant. M.Sc. Thesis, Fac. Agri., Cairo Univ., Egypt, 132pp.

Foyer C.H., Lelandais M. and Kunert K.J. (1994a). Photooxidative stress in plants. Physiol. Plant., 92:696-717.

Foyer C.H., Descourvieres P. and K.J. Kunert (1994b). Protection against oxygen radicals: an important defense mechanism studied in transgenic plants. Plant Cell Environ., 17:507-523.

Galston A.W. (1983). Polyamines as modulators of plant development. Bioscience, 33:382388.

Kosson R. and Prange R.K. (2005). The occurrence, physiological role and nutritive importance of polyamines in vegetables and fruits. Vegetable Crops Research Bulletin, 63: 5-24.

Kuchen G.D. and Phillips G.C. (2005). Role of polyamines in apoptosis and other recent advances in plant polyamines. Crit. Rev. plant Sci ., 24 : 123-130.

Mahgoub M. H., Abd El-Aziz N. G. and Mazhar A. M. (2011). Response of Dahlia pinnata L. to foliar spray with putrescine and thiamine on growth, flowering and photosynthetic pigments. AmericanEurasian J. Agric. \& Environ. Sci., 10 (5):769-775.

Munne-Bosch S. and Alegre L. (2002). The function of tocopherol and tocotrienols in plants. Crit. Rev.plant Sci., 21:31-57.

Reda F., Abdel-Rahim E. A., El-Baroty G.S.A. and Ayad H. S. (2005). Response of essential oil, phenolic components and polyphenol oxidative activity of thyme (Thymus vulgaris L.) to some bioregulators and vitamins. Int. J. Agric. Biol., 7(5):735739.

Slocum R.D. and Galston A.W. (1985). Changes in polyamines associated with post fertilization and development in tobacco ovary tissue. Plant Physiol., 79: 336-343.

Snedecor G. W. and Cochran W. G. (1980). Statistical Methods. 7th ed. Iowa Stat. Univ., Press, Ames. Iowa, USA.

Talaat I. M. and Gamal El-Din K. M. (2005). Physiological effect of putrescine and heat hardening on Nigella sativa L. plants. Int. J. Agri. Biol., 7(3): 358-362.

Youssef N. M. (2011). Physiological studies on some Populus species. M.Sc. Thesis, Fac. Agri., Cairo Univ., Egypt, 132pp.

Youssef A. A., El-Mergawi R. A. and Abd-ElWahed M. S. A. (2004a). Effect of putrescine and phenylalanine on growth and alkaloid production of some Datura species. J. Agric. Sci. Mansoura Univ., 29: 4037-4053.

Youssef A. A., Mahgoub M. H. and Talaat I. M. (2004b). Physiological and biochemical aspects of Matthiola incana plants under the effect of putrescine and kinetin treatments. Egypt. J. Appl. Sci., 19(9B): 492-510.

Zhang R., Schmidt E. and Zhang X. Z. (2000). Hormone containing products impact on antioxidant status of tall fescue and creeping betagrass subjected to drought. Crop. Sci., 40: 1344-1349. 


\section{تأثير البتروسين والألفا توكوفيرول على النمو الخضري والزهري

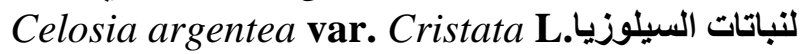

$$
\begin{aligned}
& \text { السعدي بدوي محمد - نرمين طه شنن - منى حسن محجوب* - ههى عبدالعال حجازي }
\end{aligned}
$$

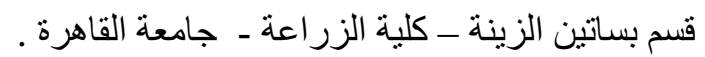

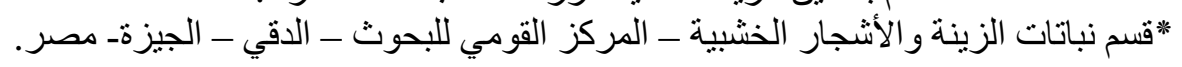

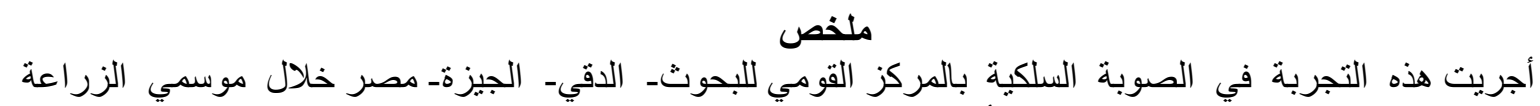

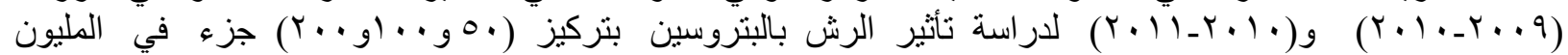

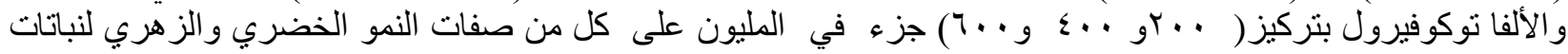

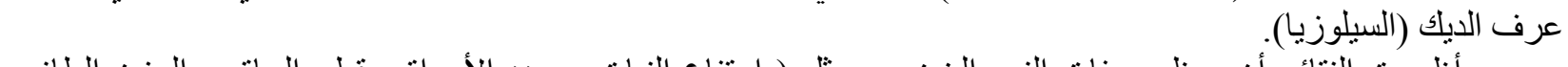
أظهرت النتائج أن معظم صفات النمو الخضري مثل ( ارتفاع النبات و وعدد الأوراق وقطر الساق و والوزن الطازج

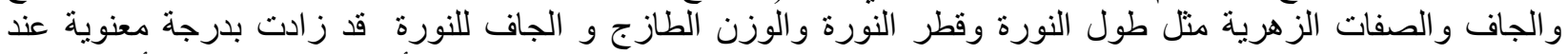

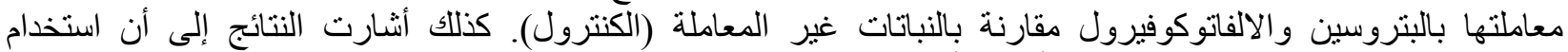

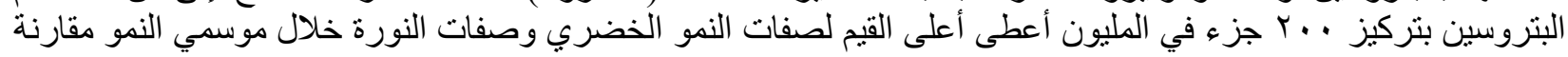

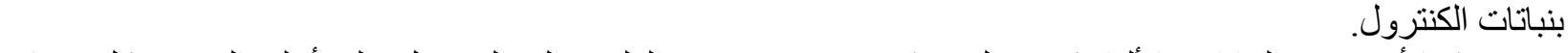
كما أدى رش النباتات بالألفاتوكوفيرول بتركيز .ــ جزء في المليون إلى الحصول على أعلى القيم في كل صفات

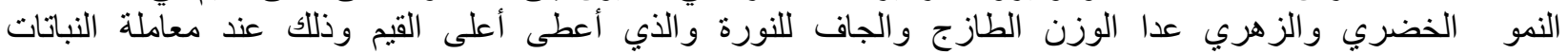

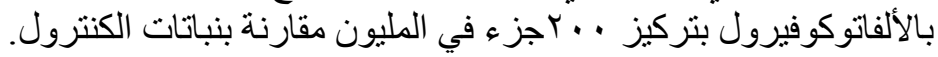

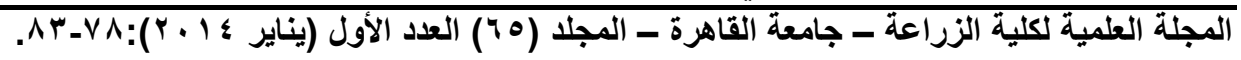

